\title{
PERSEPSI PIMPINAN BADAN KONTAK MAJELIS TAKLIM, AISYIAH, WANITA SYARIKAT ISLAM, FATAYAT NU, DAN KERUKUNAN WANITA ISLAM DI KOTA MANADO TENTANG POLIGAMI
}

\author{
Nusri Taroreh \& Ahmad Rajafi* \\ Institut Agama Islam Negeri Manado, Indonesia \\ Email: nusritaroreh@gmail.com
}

\begin{abstract}
The perception of Muslim women who serve as leaders of Islamic organizations in Manado city about polygamy is very important to examine, considering that Manado city is a minority of Muslim region in Indonesia. The result showed that all leaders agreed about polygamy. It was one of the teachings of Islam contained in the Qur'an. However, its implementation in this era needs to be examined for its validity. This was considered that polygamy in this era is more dominated by the desire for sexual only which leads to the disadvantages and not for the path of benefits. Therefore, they agreed that the legal rules in Indonesia regarding marriages that affirm open monogamy as the principle of marriage are very responsive, and the wife's permission is a healthy path of polygamy if it is desirable.
\end{abstract}

Keywords: Perception, BKMT Leaders, Aisyiah, SI Women, Fatayat NU, KWI, Manado City, Polygamy

\begin{abstract}
Abstrak
Persepsi muslimah yang menjabat sebagai pimpinan ormas Islam di Kota Manado seperti Badan Kontak Majelis Taklim (BKMT), Aisyiah, Wanita Serikat Islam, Fatayat NU, dan Kerukunan Wanita Islam (KWI) tetang poligami adalah fokus dalam penelitian ini, mengingat Kota Manado adalah wilayah muslim minoritas di Indonesia. Hasilnya adalah, bahwa semua pimpinan sepakat bahwa poligami adalah salah satu ajaran agama Islam yang tertuang di dalam al-Qur'an, namun implementasinya di era ini yang perlu ditelaah keabsahannya. Hal ini mengingat bahwa poligami di era ini lebih didominasi oleh kehendak nafsu seksual semata yang menjurus pada kemudharatan dan bukan untuk jalan kemaslahatan. Oleh karenanya, mereka sepakat bahwa aturan hukum di Indonesia tentang perkawinan yang menegaskan monogami terbuka sebagai asas perkawinan sangat responsif, dan izin istri adalah jalan poligami yang sehat jika diinginkan.
\end{abstract}

Kata Kunci: Persepsi, Pimpinan BKMT, Aisyiah, Wanita SI, Fatayat NU, KWI, Kota Manado, Poligami

\section{Pendahuluan}

Perdebatan tentang poligami seolah tidak ada ujungnya, karena baik yang menerima maupun yang menolak sama-sama memiliki argumentasi normatif. Bagi mereka yang menerima, mendasarkan argumentasinya pada Firman Allah

* Dosen Prodi Hukum Keluarga (Ahwal Syakhshiyah) Fakultas Syariah Institut Agama Islam Negeri (IAIN) Manado. 
swt dalam QS. an-Nisa' (4) ayat 3. Sedangkan yang melakukan penolakan atas poligami, juga bersandar pada Firman Allah swt dalam QS. an-Nisa' (4) ayat 129.1

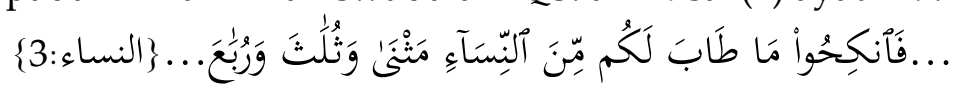

Artinya: "...maka nikahilah perempuan (lain) yang kamu senangi: dua, tiga atau empat..."

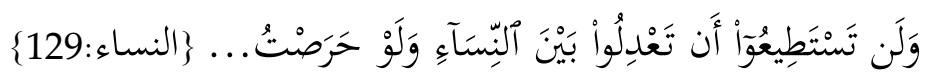

Artinya: "Dan kamu tidak akan dapat berlaku adil di antara istri-istri(mu), walaupun kamu sangat ingin berbuat demikian..."

Demi mengakomodir kedua ayat tersebut, Negara melalui Undangundang Nomor 1 Tahun 1974 menggunakan teori pertengahan dengan jalan aljam'u wa at-taufiq dan merumuskan Pasal 3 sampai dengan Pasal 5. Inilah yang selanjutnya dikenal dengan istilah monogami terbuka, bukan monogami tertutup, yakni sorang pria hanya boleh memiliki satu orang isteri, namun dalam hal-hal tertentu yang dibenarkan oleh hukum melalui pengajuan di Pengadilan, maka poligami diperbolehkan.

Secara tidak langsung, norma agama dan yuridis tersebut telah melahirkan persepsi yang beragam di kalangan masyarakat, termasuk di Kota Manado, bahkan oleh para pemuka agama Islam dari kelompok muslimah yang tergabung di dalam organisasi masyarakat Islam. Akibat perbedaan pandangaan di kalangan umat Islam tersebut juga berimplikasi negatif dalam cara pandang non-muslim tentang Islam. Untuk itu dibutuhkan penelitian tentang persepsi muslimah di wilayah minoritas yakni Kota Manado yang dirujuk dari beberapa organisasi kemasyarakatan Islam seperti Pengurus Badan Kontak Majelis Taklim Kota Manado, Pengurus Aisyiah Kota Manado, Pengurus Wanita Syarikat Islam Kota Manado, Pengurus Fatayat NU Kota Manado, dan Pengurus Kerukunan Wanita Islam Kota Manado.

\section{Metodologi Penelitian}

Ini adalah penelitian lapangan dengan pendekatan kualitatif, dan mengambil data melalui wawancara dan dokumentasi pada organisasi kemasyarakatan Islam yang dikelola oleh kelompok muslimah seperti Pengurus Badan Kontak Majelis Taklim Kota Manado, Pengurus Aisyiah Kota Manado, Pengurus Wanita Syarikat Islam Kota Manado, Pengurus Fatayat NU Kota Manado, dan Pengurus Kerukunan Wanita Islam Kota Manado. Pengolahan datanya melalui proses pengumpulan data, reduksi data, display data, dan penarikan kesimpulan. ${ }^{2}$ Dengan proses tersebut diharapkan dapat memberikan kesimpulan yang didukung dengan data yang sesuai.

${ }^{1}$ Ahmad Rajafi, Nalar Hukum Keluarga Islam di Indonesia (Yogyakarta: Istana Publishing, 2015), 52-55.

2 Sugiyono, Memahami Penelitian Kualtatif (Cahaya Alfabeta, 2008), 52. 


\section{Literatur Review}

Literatur pertama yang relevan dengan artikel ini adalah buku yang ditulis oleh Ahmad Rajafi dengan judul Cerai Karena Poligami. Dalam bukunya tersebut, dijelaskan bahwa perlu diketengahkan sebuah pemahaman yang lugas dan komprehensif tentang poligami, di mana poligami yang awalnya adalah baik dan bernilai pahala, akan menjadi perbuatan yang tercela dan bernilai dosa ketika keluar dari norma hukum beserta substansinya yang diraih dari pemahman atas maqashid asy-syari'ah yang terdiri dari kewajiban primer berupa menjaga agama, jiwa, keturunan, akal, harta dan kehormatan. ${ }^{3}$ Distingsinya dengan penelitian ini ada pada sisi cakupan penelitian, di mana buku Rajafi bersifat general, sedangakn artikel ini lebih spesifik melihat persepsi perempuan yang menjabat sebagai pemimpin ormas Islam khusus muslimah di Kota Manado.

Literatur kedua yang juga relevan adalah artikel jurnal yang ditulis oleh Dewani Romli dengan judul Persepsi Perempuan Tentang Poligami (Studi Pada Badan Musyawarah Organisasi Islam Wanita Indonesia Provinsi Lampung). Hasilnya ditemukan bahwa BMOIWI Provinsi Lampung menyetujui praktik poligami dengan syarat harus mendapatkan persetujuan dari pasangannya yang disahkan oleh Pengadilan Agama, dan suami memiliki kemampuan memberi nafkah lahir dan batin yang layak serta mampu berlaku adil terhadap istri-istri dan anak-anak mereka. ${ }^{4}$ Distingsinya dengan artikel ini adalah, pada sisi locus penelitian, di mana Romli locusnya di Provinsi Lampung, sedangkan artikel ini locus penelitiannya di Kota Manado.

Literatur selanjutnya yang relevan adalah artikel jurnal yang ditulis oleh Shinta Dewi Rismawati dengan judul Persepsi Poligami di Mata Perempuan Pekalongan. Dalam artikel tersebut dijelaskan bahwa wanita Pekalongan memiliki persepsi yang beragaam tentang poligami, dan kebanyak dari mereka menolak adanya poligami dengan ragam alasan pula, dan alasan utamnaya adalah poligami berpotensi memunculkan kekerasan dalam rumah tangga. ${ }^{5}$ Sisi distingsinya dengan artikel ini adalah pada locus dan fokus penelitian, di mana Rismawati locus penelitiannya di Pekalongan dengan locus penelitian ini di Manado, serta fokus Rismawati pada persepsi secara genaral, sedangkan artikel ini khusus diambil dari pimpinan ormas Islam khusus muslimah saja.

Berdasarkan ketiga literatur tersebut maka artikel ini belum pernah ada yang mengkajinya dan substansi kajian dari ketiga litertur tersebut berbeda dengan artikel ini. Terlebih lagi bahwa artikel ini ditelaah di wilayah muslim minoritas yakni Kota Manado dengan soliditas yang cukup tinggi antar sesama umat Islam dengan asumsi ketegangan antar umat Islam - termasuk efek dari problem rumahtangga - menjadi rendah.

${ }^{3}$ Ahmad Rajafi, Cerai Karena Pologami: Tinjauan Figh Islam Nusantara Terhadap Maraknya Cerai Gugat di Indonesia (Yogyakarta: Istana Publishing, 2018).

${ }^{4}$ Dewani Romli, "Persepsi Perempuan Tentang Poligami (Studi Pada Badan Musyawarah Organisasi Islam Wanita Indonesia Provinsi Lampung)," Al-'Adalah: Jurnal Hukum Islam XIII, no. 1 (Juni 2016).

${ }^{5}$ Shinta Dewi Rismawati, "Persepsi Poligami di Mata Perempuan Pekalongan," Muwâzâh 6, no. 2 (Desember 2014). 


\section{Persepsi Ketua Badan Kontak Majelis Taklim Kota Manado ${ }^{6}$}

Dalam kegiatan lapangan tersebut, penggalian informasi yang pertama adalah mengenai pemahaman para pengurus tentang QS. an-Nisa' (4) ayat 3. Mengenai hal ini, dijelaskan bahwa ayat tersebut merupakan dalil diperbolehkannya poligami dalam Islam dan tidak ada satupun umat Islam yang mampu menolaknya, karena firman Allah adalah hukum bagi umat Islam, namun perlu dibaca dan dipahami juga bagaimana tafsir tentang ayat tersebut sehingga menjadi baik dalam pelaksanaannya.

Ketika ditanyakan tentang keberadaan QS. an-Nisa' (4) ayat 129, informan menjelaskan bahwa ayat tersebut telah menjadi petunjuk akan adanya poligami yang tidak boleh dilakukan secara sembarangan dan sekehendaknya saja umat Islam, karena Allah swt memberikan penegasan bahwa yang boleh untuk melakukan poligami hanyalah orang yang mampu berlaku adil. Adil disini bukan saja tentang masalah kemapanan ekonomi atau lahiriah tapi juga tentang bathiniyiah seorang isteri yakni cinta. Menurutnya, hal yang lumrah tentang keadilan adalah dalam hal cinta, condong pada salah satunya, kemudian amalan sebagai konsekuensinya. Berbuat adil secara sempurna untuk semua, amatlah sulit. Oleh karenanya Allah memaafkannya. Sedangkan hal yang mampu suami berbuat adil, dilarang untuk tidak adil. Sehingganya, jika ada yang ingin berpoligami maka hendaknya mampu berlaku adil dan tidak hanya memperturutkan hawa nafsu, sehingga cenderung untuk tidak adil dan condong pada salah satu isteri atau bahkan sampai melalaikan nafkah atau bahkan sebenarnya tidak mampu, namun tetap memaksa untuk berpoligami.

Pertanyaan selanjutnya adalah tentang pemahaman informan mengenai hukum poligami. Dalam hal ini, informan menyebutkan bahwa hukum poligami itu diperbolehkan atau mubah dan bukan wajib serta sunnah, terlebih lagi Allah swt telah menjelaskannya secara langsung di dalam al-Qur'an, akan tetapi tentu dengan syarat-syarat tertentu, tidak diterapkan berdasarkan nafsu semata. Paling tidak alasan utama diperbolehkannya poligami itu karena pasangannya tidak dapat memberikan keturunan, tidak bisa memenuhi hak-haknya sebagai seorang isteri, mempunyai penyakit yang tidak biasa disembuhkan, cacat seumur hidup, dan lain sebagainya yang tentunya ada masalah besar pada pasangannya.

Adapun ketika ditanyakan tentang pendapat informan jika poligami masuk ke dalam rumahtangganya, informan menjelaskan baha ia menerima poligami dengan syarat-syarat tertentu, tapi jika hal tersebut masuk ke dalam keluarga maka informan mengatakan perlu pikir-pikir terlebih dahulu, karena poligami itu tidak semudah yang dipikirkan. Ada begitu banyak pertimbanganpertimbangan sehingga tidak ada yang tersakiti. Dan kalau merujuk pada perilaku Nabi Muhammad saw maka sesungguhnya yang dinikahi oleh Nabi Muhammad saw itu adalah para janda dan bukan perempuan-perempuan yang masih muda dan perawan.

${ }^{6}$ Fatma Sugeha, Ketua Pengurus Badan Kontak Majelis Taklim Kota Manado Tentang Poligami, 19 Oktober 2018. 
Pertanyaan berikutnya adalah tentang izin suami kepada isteri jika ingin melakukan praktik poligami. Mengenai hal ini informan menyebutkan bahwa penting adanya izin dari isteri jika suami ingin melakukan poligami, karena informasi tentang kondisi keluarga bisa didapat dari pasangannya, dan yang terbaik itu kalau isterinya sendiri yang mencarikan pasangan untuk suaminya bukan cari sendiri oleh suami, apalagi diam-diam. Jangan sampai susahnya dirasakan isteri pertama dan nikmatnya hanya dirasakan oleh isteri mudanya.

Terakhir adalah pertanyaan mengenai pemahaman informan tentang hukum yang dirasa lebih baik dalam menjelaskan tentang poligami. Dalam hal ini informan menyebutkan bahwa ketentuan hukum yang ada di Indonesia itu sudah sangat baik untuk memperkatat praktik poligami, agar suami-suami tidak begitu saja ingin menikah lagi atau berpoligami tanpa alasan yang tepat.

\section{Persepsi Ketua Pengurus Daerah Aisyiah Kota Manado}

Sebelum pertanyaan yang sama diajukan, informan ditanya terlebih dahulu tentang adakah keputusan organisai yang secara spesifik membahas tentang poligami. Mengenai hal ini, informan menjawab bahwa tidak ada keputusan yang membahas hal tersebut karena al-Qur'an sudah memeberikan penjelasan tentang hal tersebut.

Namun meskipun demikian, informan menolak pratik poligami di era ini. Alasannya adalah karena pengalamannya yang menjadi "korban" poligami. Informan mengungkapkan, bahwa ketika suaminya yang telah membina rumah tangga berpuluh tahun lamanya mengutarakan niat untuk poligami - meskipun dia sendiri memahami bahwa poligami itu dicantumkan dalam al-Qur'an dengan persepsi dan tingkat pemahaman yang berbeda - namun dirinya merasa dibohongi setelah suaminya mapan dan punya kedudukan, baru berkeinginan untuk poligami, karenanya sepontan informan langsung menjawab untuk mengizinkan suaminya berpoligami namun harus menceraikan informan terlebih dahulu.

Menurutnya, kaum laki-laki yang berpoligami kebanyakan mencari alasan dan cara sendiri agar keinginannya terlaksana. Hampir tidak ada laki-laki di Manado yang poligami semata-mata karena sunnah menolong atau melindungi perempuan yang memang seharusnya mendapat perlindungan karena berbagai sebab, melainkan karena nafsu seksual atau kebutuhan biologis.

Lalu ketika ditanya tentang pendapatnya mengenai ayat al-Qur'an yang menegaskan bahwa tidak akan suami itu berlaku adil dalam berpoligami, dengan sigap infoman menjawab bahwa pada dasarnya monogami ataupun poligami itu sama baiknya. Hal yang menentukan mana yang lebih baik untuk suatu keluarga adalah sifat dan keadaan suaminya. Artinya, jika sudah merasa nyaman dengan satu isteri kenapa harus mencari lagi, kecuali jika isterinya tersebut mandul atau "tidak memuaskan", maka "lebih baik poligami".

Baginya, kesulitan dan tantangan keluarga poligami adalah keadilan, seperti dalam membagi waktu dan harta, bahkan gaji suamipun harus dibagi.

${ }^{7}$ Nikmah Kadir, Ketua Aisyiah Kota Manado, 8 Oktober 2018. 
Untuk itu, ia setuju dengan hukum tentang poligami dengan syarat yang ketat, karena menurutnya poligami itu tidak sesederhana seperti yang dibicarakan. Diakhir keterangannya, ia menjelaskan secara spekulatif bahwa jika seluruh Aisyiyah disurvei, maka 90\% mereka akan menyatakan tidak setuju dengan poligami.

\section{Persepsi Ketua Pengurus Wanita Syarikat Islam Kota Manado ${ }^{8}$}

Pertanyaan pertama adalah mengenai pemahaman informan terhadap QS. an-Nisa' (4) ayat 3 yang menjelaskan tentang poligami. Dalam hal ini menurutnya poligami adalah sistem perkawinan yang memperbolehkan seorang laki-laki memiliki isteri lebih dari satu, dan tercantum di dalam al-Quran dan al-Hadis, tetapi informan menolak praktek poligami. Menurtnya, ayat tersebut tidak secara spesifik menjelaskan tentang poligami, akan tetapi tentang penjagaan kehormatan keluarga yang dikomandoi oleh seorang suami, ketika suami sudah tidak ada, maka yang berkecukupan diperbolehkan untuk melakukan poligami dengan janda tersebut, dan bukan karena dorongan nafsu. Namun yang terjadi saat ini menurutnya, lebih banyak yang melakukan poligami karena dorongan hawa nafsu, karena itu informan menolak model poligami saat ini.

Pertanyaan kedua adalah mengenai pemahaman informan tentang QS. anNisa' (4) ayat 129 yang menjelaskan bahwa suami itu tidak akan dapat berlaku adil di antara isteri-isterinya meskpiun ia telah berusaha. Dalam menjawab hal ini, informan langsung menegaskan bahwa ayat tersebut sudah betul adanya dan ia sangat mendukung ayat tersebut. Untuk itu ia menjelasn bahwa poligami sulit untuk diterapkan, karena akan menyakiti pasangannya yang selama ini bekerjasama membangun rumah tangga, dan rusak karena adanya orang ketiga.

Menurutnya adil itu mudah diucapkan akan tetapi sulit diterapkan, dan tujuan perkawinan itu pada dasarnya adalah untuk membentuk keluarga yang harmonis dan bahagia. Harmonis dalam menggunakan hak dan kewajiban anggota keluarga, sejahtera artinya terciptanya ketenangan lahir batin disebabkan terpenuhinya keperluan hidup lahir dan batinnya, sehingga timbullah kebahagiaan, yakni kasih sayang antar anggota keluarga. Akan tetapi kalau sudah poligami tentu akan sangat sulit untuk meraih kebahagian tersebut, khususnya masalah batin.

Pertanyaan selanjutnya adalah tentang pendapat informan mengenai hukum poligami. Menurutnya, hukum poligami itu sudah ada dalam al-Qur'an, diperbolehkan ketika untuk kebutuhan yang mendesak. Bahkan informan beralasan bahwa Nabi Muhammad saw menolak kehendak Ali menantunya ketika ingin berpoligami sedangkan Fatimah masih ada. Sehingga Ali baru berpoligami setelah Fatimah meninggal dunia. Perilaku Nabi Muhammad saw kepada menantunya tersebut seharusnya menjadi contoh agar tidak mudah untuk berpoligami. Mengenai hal ini, argumentasi bahwa Allah swt telah menjelaskan di dalam al-Qur'an adalah fakta yang tidak bisa dipungkiri, namun bukan berarti

${ }^{8}$ Zaenab Hamzah, Ketua Wanita Syarikat Islam Kota Manado, 10 Oktober 2018. 
penerapannya tanpa sebab hukum, apalagi jika sekedar ingin melampiaskan nafsu seksual semata.

Pertanyaan selanjutnya adalah tentang pendapat informan mengenai apakah informan menerima adanya praktik poligami dalam Islam atau tidak, dan apa alasan. Mengenai hal ini, informan menjawab bahwa ia menolak poligami dengan beberapa alasan, seperti:

1. Lemahnya laki-laki memenuhi aspek keadilan ketika sudah berpoligami, apalagi isteri kedua, ketiga dan seterusnya lebih muda dan menggairahkan;

2. Isteri pertama yang berjuang dari awal, susah senang bersama agar kelak bisa hidup bahagia bersama suaminya, setelah berkecukupan malah menikah lagi. Hal ini tentunya menyakiti perasaan wanita, atau isteri merasa sangat dikhianati;

3. Poligami cenderung berpontesi melecehkan perempuan, sehingga menurutnya tidak perlu dilakukan karena dalam banyak hal poligami hanya akan memberikan privelege bagi kaum laki-laki atas perempuan untuk mendominasi pengambilan keputusan dalam rumah tangga. Sehingga isteri seringkali menjadi masyarakat kelas dua di dalam rumahnya dan seolah menumpang di rumah suaminya;

4. Dan yang jelas adalah, bahwa poligami merupakan bentuk pengkhianatan atas ikrar perkawinan yang sudah dibacakan ketika dilangsungkannya pernikahan. Jika ketika di awal menikah suami sudah mempersiapkan dan mengucapkan bahwa kelak suami akan berpoligami, tentunya isteri dengan tegas akan menyatakan penolakan atas pernikahan tersebut.

Pertanyaan selanjutnya adalah mengenai pendapatnya tentang izin suami untuk poligami kepada isterinya. Dalam hal pertanyaan ini, informan sangat setuju jika kehendak poligami itu dimusyawarahkan bersama isteri, atau bahkan dengan seluruh anak-anaknya sebagai anggota keluarga, karena prinsip keluarga itukan harus bahagia, yakni bahagia seluruh keluarga bukan dirasakan sendiri apalagi sepihak saja. Dengan bermusyawarah akan melahirkan keterbukaan dan saling menjaga perasaan. Kebutuhan apa yang belum tercukupi oleh isteri sehingga suami berkeinginan untuk menikah kembali. Isteri harus mengetahu secara detil seluruh alasan suami untuk berpoligami. Terlebih lagi apakah ketika telah berpoligami suami mampu untuk berlaku adil atau tidak.

Pertantaan terakhir adalah tentang pendapatnya mengenai ketentuan hukum yang tepat dalam menjelaskan tentang poligami. Menurut informan bahwa hukum perkawinan yang ada di Indonesia ini sudah cukup baik, dan meskipun dalam hati kecil setuju dengan poligami, akan tetapi informan menggarisbawahi bahwa poligami dapat dibenarkan apabila bersifat emergency atau keadaan darurat, misalnya ketiadaan seorang anak dalam sebuah perkawinan, sakit yang sangat parah sekali, dan lain sebagainya.

Lebih lanjut dijelaskan bahwa bagi laki-laki yang sudah beristeri, jika ingin melakukan poligami maka harus memperhatikan kemampuannya, baik kemampuan lahir maupun batin. Di samping itu hal penting yang sebaiknya 
dilakukan sebelum melakukan poligami adalah bermusyawah dan meminta pertimbangan serta izin isteri.

\section{Persepsi Ketua Pengurus Cabang Fatayat NU Kota Manado ${ }^{9}$}

Pertanyaan pertama mengenai pemahaman informan terhadap firman Allah swt dalam al-Qur'an ayat 3 dari surat an-Nisa' (4) yang menjelaskan tentang poligami. Mengenai hal ini, informan menjelaskan bahwa ayat tersebut tidak bersifat umum, sehingga tidak bisa diterapkan kepada semua umat Islam, yakni untuk keadaan yang tidak biasa atau darurat, dan ayat tersebut harus diterima keberadaannya, meskipun kondisi hukum berkewajiban untuk membaca ulang dalam hal pelaksanaannya. Lebih jauh informan yang juga sebagai anggota Dewan Kota Manado tersebut menjelaskan, bahwa praktik poligami bukan bangunan ideal rumah tangga Muslim. Bangunan ideal rumah tangga Muslim adalah monogami. Praktik poligami adalah sebuah pengecualian dalam praktik rumah tangga. Praktik ini bisa dilakukan dalam kondisi darurat yang membolehkan seseorang menempuh praktik poligami.

Ketika ditanya tentang pemahaman informan atas firman Allah swt dalam QS. an-Nisa' (4) ayat 129 yang menjelaskan bahwa suami itu tidak akan dapat berlaku adil di antara isteri-isterinya, informan segera menegaskan kebenaran ayat tersebut, dan mengatakan bahwa tidak akan ada suami yang mampu adil dalam berpoligami. Untuk itu, suami seharusnya menyediakan seluruh kebutuhan isteri sehingga suami tidak lagi tertarik dengan wanita lain, karena pada dasarnya laki-laki yang berkeinginan poligami itu disebabkan faktor mata yang tidak pernah merasa puas. Dengan demikian, memberikan fasilitas yang optial kepada isteri menjadi jalan maslahat agar suami terhindar dari keinginan berpoligami atas dasar nafsu.

Pertanyaan selanjutnya adalah tentang pendapat informan mengenai hukum poligami. Bagi informan, meskipun hukum poligami itu dibenarkan oleh Allah dalam al-Qur'an namun pelaksanaannya saat ini di masyarakat informan menolaknya dan tidak setuju. Setiap pasangan poligami yang diamatinya, tidak pernah sesuai dengan harapan dan tujuan perkawinan. Jika tidak sembunyisembunyi dengan isteri yang sah atau isteri pertamanya, maka kehendak untuk berpoligami akan menjadi terganggu, maka dengan sendirinya situasi dan kondisi rumah tangga mereka yang berpoligami tersebut selamanya tidak akan pernah tenang atau selalu dibayang-bayangi oleh ketakutan diketahui oleh isteri pertama.

Ketika ditanya tentang pendapatnya mengenai penerimaannya atas praktik poligami dalam rumahtangganya, informan dengan tegas menolak karena bisa dipastikan akan menimbulkan masalah. Menurutnya, selalu ada masalah dalam poligami di era ini karena di awali dengan masalah. Karenanya, informan mengajukan satu syarat setuju poligami jika waktu pernikahan pertama sudah menyampaikan pernyataan kepada isteri bahwa dia akan poligami.

${ }^{9}$ Fatma Bin Syekh Abu Bakar, Ketua Pengurus Cabang Fatayat NU Kota Manado, 12 Oktober 2018 . 
Komunikasi antara suami-isteri mengenai poligami hanya akan membuka permasalah baru, maka tidak perlu untuk dibicarakan lebih lanjut. Sebaiknya menyiapkan keluarga yang bahagia itulah yang harus terus dibicarakan dan dikomunikasikan. Karena tidak membahas poligami saja sudah begitu banyak masalah dalam keluarga, apalagi harus disulut oleh api asmara jilid dua berbalut sunnah poligami. Atas dasar pendapatnya itu, maka informan beranggapan bahwa hukum di Indonesia saat ini yang menekan adanya hukum monogami dan mempersulit poligami adalah benar. Sebagai umat Islam tentu tidak bisa menolak adanya poligami dalam Islam, akan tetapi bukan berarti tidak bisa menolak praktik poligami saat ini karena konteks hukum yang berbeda.

\section{Persepsi Ketua Pengurus Kerukunan Wanita Islam (KWI) Kota Manado ${ }^{10}$}

Pertanyaan pertama adalah tentang pemahaman informan terhadap QS. an-Nisa' (4) ayat 3 yang menjelaskan tentang poligami, di mana Allah swt menjelaskan tentang menikah hingga empat orang isteri. Mengenai hal ini, informan menegaskan bahwa ayat tersebut merupakan dalil diperbolehkannya poligami dalam Islam dan umat Islam harus mengimani firman Allah swt tersebut meskipun dirasa tidak sesuai dengan hati nurani, karena firman Allah swt adalah hukum bagi umat Islam, namun perlu dibaca dan dipahami juga bagaimana para ulama membahas tentang hukum poligami, seperti penjelasan Muhammad Quraish Shihab yang juga mengatakan bahwa poligami baru bisa diterapkan dengan aturan-aturan yang bukan mengedepankan hawa nafsu sehingga pelaksanaannya bisa menjadi baik.

Disamping itu perlu dimaklumi bahwa ayat ketiga dari surat an-Nisa' tersebut tidak bermaksud menganjurkan apalagi mewajibkan kepada para suami untuk berpoligami. Ayat ini berbicara tentang kebolehan berpoligami merupakan pintu yang sempit yang semua orang diperbolahkan melaluinya. Hanya mereka yang membawa bendera darurat yang memungkinkan untuk mendapat izin melaluinya. Islam mendambakan kebahagian keluarga, kebahagiaan yang antara lain didukung oleh cinta kepada pasangan, cinta yang sebenarnya menuntut agar seseorang tidak mencintai kecuali pasangannya.

Pertanyaan kedua adalah tentang pemahaman informan tentang QS. anNisa' ayat 129 yang menjelaskan bahwa suami itu tidak akan dapat berlaku adil di antara isteri-isterinya, walaupun kamu sangat ingin berbuat yang demikian. Menurut informan, bahwa ayat tersebut telah menjadi petunjuk akan adanya poligami yang tidak boleh dilakukan secara sembarangan dan sekehendaknya saja umat Islam, karena Allah swt memberikan penegasan bahwa yang boleh untuk melakukan poligami hanyalah orang yang mampu berlaku adil. Adil disini bukan saja tentang masalah kemapanan ekonomi atau lahiriah tapi juga tentang bathiniyiah seorang isteri yakni cinta, meskipun ada pendapat yang mengatakan bahwa keadilan yang diharuskan dan disyariatkan dalam legalitas hukum poligami mencakup keadilan secara materi serta yang dapat dijangkau oleh suami berupa keadilan dalam pemberian nafkah, keadilan dalam pemberian sandang,

${ }^{10}$ Sartje Mokoginta, Ketua Kerukunan Wanita Islam Kota Manado, 15 Oktober 2018. 
pangan, dan papan. Sementara itu keadilan dalam kecintaan dan kecenderungan hati atau semisalnya, itulah bentuk keadialan yang tidak di haruskan.

Pertanyaan ketiga adalah tentang pemahaman informan tentang hukum dari poligami. Mengenai hal ini informan menyebutkan bahwa dibolehkannya poligami apabila si isteri tidak dapat memberikan keturunan, tidak mampu untuk melayani suami, atau dalam istilah lain memiliki penyakit yang susah untuk disembuhkan dan merugikan pasangnannya, dengan demikian maka Islam memberikan solusi yang terbaik yaitu "poligami" dengan syarat suami bisa berlaku adil terhadap isteri-isterinya, baik pangan, sandang, dan papan, maupun kasih sayang. Tetapi apabila yakin atau ragu tidak bisa untuk berbuat adil diantara isteri-isterinya maka cukup hanya satu isteri saja, agar tercipta keluarga yang sakinah mawaddah warahmah, sesuai dengan tujuan perkawinan yang telah disyariatkan Islam.

Pertanyaan keempat adalah mengenai pendapat informan apakah informan menerima praktik poligami dalam kehidupannya. Mengenai hal ini, informan menerima adanya poligami dengan syarat-syarat tertentu. Ada begitu banyak pertimbangan jika suami ingin berpoligami sehingga tidak ada yang tersakiti. Adapun ketika ditanyakan tentang izin suami kepada isteri jika ingin melakukan praktik poligami, informan dengan tegas menyebutkan bahwa penting adanya izin dari isteri jika suami ingin melakukan poligami, karena informasi tentang kondisi keluarga bisa didapat dari pasangannya, dan yang terbaik itu kalau isterinya sendiri yang mencarikan pasangan untuk suaminya bukan cari sendiri oleh suami, apalagi diam-diam. Jangan sampai susahnya dirasakan isteri pertama dan nikmatnya hanya dirasakan oleh isteri mudanya.

Pertanyaan terakhir adalah mengenai pemahaman informan tentang hukum yang dirasa lebih baik dalam menjelaskan tentang poligami. Dalam hal ini informan menyebutkan bahwa ketentuan hukum yang ada di Indonesia itu sudah sangat baik untuk memperkatat praktik poligami.

\section{Analisis Hasil Lapangan}

Berdasarkan penggalian informasi kepada ketua-ketua organisasi wanita Islam di Kota Manado, maka dapat dipahami bahwa mereka memiliki pendapat yang sama tentang keabsahan poligami dalam Islam, karena Allah swt telah menyebutkan secara jelas di dalam al-Qur'an. Akan tetapi yang mereka permasalahkan adalah praktik poligami saat ini yang tidak lagi mengikuti ajaran Islam, yakni untuk menjaga marwah para wanita khususnya janda yang ditinggal wafat suaminya berjihad di jalan Allah swt. Bukan praktik poligami yang hanya mengejar hawa nafsu seksual sehingga menyakiti dan mencederai perasaan dan psikologis istri serta anggota keluarga lainnya.

Poligami di zaman sekarang bukanlah sebuah anjuran karena sudah di luar konteks yang sebenarnya sebagaimana di ajaran dari Rasulullah Muhammad saw. untuk itulah mereka menyepakati bahwa saat ini poligami memang rawan konflik baik sebelum maupun sesudahnya yang mengancam keutuhan dan keharmonisan rumah tangga yang sudah terbangun dan yang seharusnya dijaga dan dirawat dengan baik agar lestari. Jika ditinjau dari segi perubahan sosial, 
maka alasan utama mengapa itu terjadi adalah karena prinsip poligami sudah meulai bergeser dari privilese para yang sangat sakral menjadi praktik umum yang bisa dilakukan oleh siapa saja. ${ }^{11}$

Namun demikian, harus diakui masih dimungkinkan berpoligami di zaman ini, yakni sebuah poligami yang dilatarbelakangi alasan personal seperti kebutuhan memiliki anak atau lainnya sebagaimana dilakukan Nabi Ibrahim 'alaihis salam. Dalam poligami seperti ini secara moral keputusan berpoligami hendaknya merupakan keputusan bersama antara laki-laki dan perempuan sehingga pihak suami tidak secara sepihak dan sembunyi-sembunyi melakukan poligami, apalagi dengan jumlah istri yang mencapai empat orang. Jika istri tidak memberikan rekomendasi sebagaimana sikap Elizabeth terhadap Nabi Zakaria 'alaihis salam, maka sikap tersebut secara moral sebaiknya dihormati.

Satu hal lagi yang disepakati bersama adalah bahwa aturan hukum perkawinan di Indonesia dalam Undang-undang Nomor 1 Tahun 1974 Tentang Perkawinan sudah cukup memadai dalam menegaskan konsep berkeluarga di Indonesia adalah monogami dan negara dengan tegas memberikan aturan yang mempersulit adanya praktik poligami di masyarakat musilm di Indonesia.

Atas dasar penjelasan tersebut maka tema tentang poligami dalam Islam khususnya dalam UU Perkawinan harus dibaca ulang melalui perspektif perempuan sehingga mampu melahirkan hukum yang progresif lagi responsif dan sejalan dengan kehendak maqashid al-syari'ah yang menghadirkan jalb almashalih (meciptakan kemaslahatan) dan dar'u al-mafasid (mencegah adanya kerusakan dan keburukan).

Maksudnya adalah, bahwa semangat yang dibawa syariat semuanya adalah spirit mashlahah, (praktiknya) bisa menolak mafsadah (tadra'u al-mafsadah) atau membawa kebaikan (jalb al mashalih). Maka, jika di dalam al-Qur'an tertuang kalimat hai orang-orang yang beriman, hai manusia, dan lain sebagainya, maka perhatikan wasiat setelah kata panggilan (nida') itu. Pastinya tidak akan ditemukan kalimat selain kebaikan termasuk dalam ayat tentang perkawinan yang diawali dengan kalimat tersebut. Intinya adalah, bahwa Allah swt akan selalu memotivasi hambanya untuk mengerjakannya, atau kejelekan yang diperintahkan agar selalu dihindari.

\section{Kesimpulan}

Persepsi ketua-ketua organisasi Islam bagi muslimah di Kota Manado terhadap praktik poligami memiliki kesamaan dalam hal keabsahannya dalam Islam, dan mereka juga sepakat bahwa poligami di era ini sudah melenceng dari tuntunan ajaran Islam karena tidak untuk menjaga marwah para kaum muslimah khususnya para janda $f i$ sabilillah, tapi hanya untuk menunaikan nafsu seksual semata sehingga mencederai psikologis pasangannya dan seluruh anggota keluarga lainnya. Untuk itu, mereka juga sepakat bahwa aturan hukum

${ }^{11}$ Ach. Faisol, "Perubahan Sosial Dalam Praktik Poligami di Indonesia Perspektif Analisis Teori Faktor Independen Neil J. Smelser," Jurnal Ilmiah Vicratina 10, no. 2 (November 2016): 5. 
ADHKI: Journal of Islamic Family Law

perkawinan di Indonesia sudah sangat responsif dalam menegaskan konsep monogami terbuka sebagai azas perkawinan di Indonesia.

\section{Daftar Pustaka}

Abu Bakar, Fatma Bin Syekh. Ketua Pengurus Cabang Fatayat NU Kota Manado, 12 Oktober 2018.

Faisol, Ach. "Perubahan Sosial Dalam Praktik Poligami di Indonesia Perspektif Analisis Teori Faktor Independen Neil J. Smelser." Jurnal Ilmiah Vicratina 10, no. 2 (November 2016).

Hamzah, Zaenab. Ketua Wanita Syarikat Islam Kota Manado, 10 Oktober 2018.

Kadir, Nikmah. Ketua Aisyiah Kota Manado, 8 Oktober 2018.

Mokoginta, Sartje. Ketua Kerukunan Wanita Islam Kota Manado, 15 Oktober 2018.

Rajafi, Ahmad. Cerai Karena Pologami: Tinjauan Figh Islam Nusantara Terhadap Maraknya Cerai Gugat di Indonesia. Yogyakarta: Istana Publishing, 2018.

- - - Nalar Hukum Keluarga Islam di Indonesia. Yogyakarta: Istana Publishing, 2015.

Rismawati, Shinta Dewi. "Persepsi Poligami di Mata Perempuan Pekalongan." Muwâazâh 6, no. 2 (Desember 2014).

Romli, Dewani. "Persepsi Perempuan Tentang Poligami (Studi Pada Badan Musyawarah Organisasi Islam Wanita Indonesia Provinsi Lampung)." Al'Adalah: Jurnal Hukum Islam XIII, no. 1 (Juni 2016).

Sugeha, Fatma. Ketua Pengurus Badan Kontak Majelis Taklim Kota Manado Tentang Poligami, 19 Oktober 2018.

Sugiyono. Memahami Penelitian Kualtatif. Cahaya Alfabeta, 2008. 